\title{
Changes of lip morphology following mandibular setback surgery using 3D cone- beam computed tomography images
}

Seung Jae Paek', Ji Yong Yoo', Jang Won Lee', Won-Jong Park², Young Deok Chee², Moon Gi Choi ${ }^{2}$, Eun Joo Choi and Kyung-Hwan Kwon ${ }^{2^{*}}$

\begin{abstract}
Background: The aims of this study are to evaluate the lip morphology and change of lip commissure after mandibular setback surgery (MSS) for class III patients and analyze association between the amount of mandibular setback and change of lip morphology.

Methods: The samples consisted of 14 class III patients treated with MSS using bilateral sagittal split ramus osteotomy. Lateral cephalogram and cone-beam CT were taken before and about 6 months after MSS. Changes in landmarks and variables were measured with 3D software program Ondemand ${ }^{\mathrm{TM}}$. Paired and independent $t$ tests were performed for statistical analysis.

Results: Landmarks in the mouth corner (cheilion, Ch) moved backward and downward ( $p<.005, p<.01$ ). However, cheilion width was not statistically significantly changed. Landmark in labrale superius (Ls) was not altered significantly. Upper lip prominence angle (ChRt-Ls-ChLt ${ }^{\circ}$ ) became acute. Landmarks in stomion (Stm), labrale inferius (Li) moved backward $(p<.005, p<.001)$. Lower lip prominence angle (ChRt-Li-ChLt ${ }^{\circ}$ ) became obtuse $(p<.001)$. Height of the upper and lower lips was not altered significantly. Length of the upper lip vermilion was increased $(p=<0.01)$, and length of the lower lip vermilion was decreased $(p<.05)$. Lip area on frontal view was not statistically significantly changed, but the upper lip area on lateral view was increased and change of the lower lip area decreased $(p>.05, p<.005)$. On lateral view, upper lip prominent point (UP) moved downward and stomion moved backward and upward and the angle of Ls-UP-Stm $\left(^{\circ}\right.$ ) was decreased. Lower lip prominent point (LP) moved backward and downward, and the angle of Stm-LP-Li ( $\left(^{\circ}\right)$ was increased. Li moved backward. Finally, landmarks in the lower incisor tip (L1) moved backward and upward, but stomion moved downward. After surgery, lower incisor tip (L1) was positioned more superiorly than stomion $(p<.05)$. There were significant associations between horizontal soft tissue and corresponding hard tissue. The posterior movement of L1 was related to statistically significantly about backward and downward movement of cheilion.

(Continued on next page)
\end{abstract}

\footnotetext{
* Correspondence: denhouse@wonkwang.ac.kr

${ }^{2}$ Department of Oral and Maxillofacial Surgery, Wonkwang Dental Research Institute, College of Dentistry, Wonkwang University, 460, Iksan-daero, Iksan, Jeollabuk-do 570-749, South Korea

Full list of author information is available at the end of the article
} 
(Continued from previous page)

Conclusions: The lip morphology of patients with dento-skeletal class III malocclusion shows a significant improvement after orthognathic surgery. Three-dimensional lip morphology changes in class III patients after MSS exhibited that cheilion moved backward and downward, upper lip projection angle became acute, lower lip projection angle became obtuse, change of upper lip area on lateral view was increased, change of lower lip area decreased, and morphology of lower lip was protruding. L1 was concerned with the lip tissue change in statistically significant way.

Keywords: Three-dimensional evaluation, Class III malocclusion, Lip morphology, Mandibular setback surgery, Cheilion

\section{Background}

Improvement in facial esthetics is one of the most important goals of orthodontic treatment and orthognathic surgery $[1,2]$. To obtain the best results, treatment planning and the assessment of results should be performed on measurable three-dimensional reproductions of the face of the patients $[3,4]$. However, the soft tissue response after mandibular setback osteotomies is subject to individual variation, and the predictability of soft tissue changes remains an important topic $[5,6]$.

Arnett and Bergman [7], Arnett et al. [2], and Proffit [8] emphasized the importance of esthetics in the frontal view, and orthodontists shifted the focus from the sagittal plane to the frontal plane when evaluating their patients and planning and assessing orthodontic treatment [9].

Researches have used lateral cephalogram to observe the aspect of transition regarding movement of soft tissue after surgery. However, it could result in inaccurate consequences in quantitative evaluation due to distortion of length, angle, and form by reflecting 3D structure in 2D plane [10]. Using laser scanner method can only measure change of soft tissue; therefore, in order to understand the change of skeletal structure, analysis of 2D radiograph should be enforced or 3D CT be re-filmed. Three-dimensional CT data, which can reduce the magnification and distortion errors of $2 \mathrm{D}$ radiographs $[11,12]$ and resolve the limitations of the 3D surface scanning system, have been used to analyze and measure the 3D structures [13-16].

Recent studies reported that in the smiles of the class III pretreatment group, both the upper and lower lips moved to an inferior position, and the upward movement of the upper lip and mouth corners was smaller, compared with those of the control group. And there were previous studies that lip morphology is different in patients with class III malocclusion when resting and smiling, and lip commissure is known to be inferiorly positioned than normal occlusion patient [17]. The morphology of lip and cheilion in class III patients may be shown in less esthetic.
In addition, there is no consensus about the changes of lip commissure related to the amount of mandibular setback. The position of lip commissure is known to be altered after orthognathic surgery. In recent study, upper lip projection angle (ChRt-Ls$\mathrm{ChLt}^{\circ}$ ) became acute and lower lip projection angle (ChRt-Li-ChLt ${ }^{\circ}$ ) became obtuse [1, 18]. Change of labrale superius (Ls), cheilion, and labrale inferius (Li) had been debated. Jung et al. reported that the landmark in Ls was not altered significantly and cheilion, Li moved backward [19]. Lim et al. reported that the landmark in Ls, cheilion, and stomion moved backward and downward and Li moved backward [20]. Baik et al. reported that Ls, cheilion, and stomion and Li moved backward and downward [21]. In most papers, the width of the lip and the position of the upper lip were not altered significantly. And, the height of the lower lip was not altered significantly in some study. While, it was significantly decreased in other study [19-21].

Recent stuides reported and discussed about threedimensional evaluation of facial soft tissue changes after mandibular setback surgery. They are consistent with the decrease of the upper lip prominence angle, increase of the lower lip prominence angle, and no change of the upper lip length. But, they are not consistent with the commissure position, the lower lip length, and so on. Also, there are few studies about the change of lip morphology according to mandibular setback surgery (MSS), according to the authors' knowledge. We analyzed the lip morphology and change of lip commissure after mandibular setback surgery according to the amount of mandibular setback only (one jaw surgery) with comparison of preoperative and postoperative lip morphology.

\section{Methods}

The samples consisted of 14 class III patients (seven males and seven females, mean age 20.3 \pm 3.1 years, range 18 to 29 years) with Alphard-3030 cone-beam CT system (Asahi Roentgen Ind. Co., Ltd.) with the following parameters: 17-s scan time and a voxel size 
of $0.39 \mathrm{~mm}$. And they had mandibular prognathism (ANB $<0^{\circ}, \quad N$-perpendicular $\mathrm{Pog}>5 \mathrm{~mm}$ ) and were conducted only MSS with bilateral sagittal split ramus osteotomy (BSSRO) by two surgeons (Table 1). Patients who had two jaw surgery or orthodontic treatment with premolar extraction or significant mandibular asymmetry (chin deviation $>5 \mathrm{~mm}$ from facial midline) or lip incompetency or functional muscular problem were excluded. To evaluate the effect of the hard tissue changes on the soft tissue changes more accurately and to exclude the effect of the maxillary surgery on the soft tissue changes, the samples need to be limited to cases with MSS.

Cone-beam CT was taken immediately before (T1) and 6 months after MSS (T2) with centric occlusion, reposed lip, and natural head position and no face movement. We chose a period 6 months after surgery as the T2 stage because we reasoned that after this period, the facial soft tissue would be stable and any subsequent changes would be small enough to be ignored [22].

The cone-beam CT raw data were reformatted into 3D views using 3D software program Ondemand ${ }^{\mathrm{m}}$ (Cybermed Inc., Seoul, Korea). Reference plane was set by using landmark on orbitale, nasion, porion, and frontozygomatic suture that were not changed after operation. It was reoriented based on this landmark. Axes of $X, Y$, and $Z$ was set in the horizontal, vertical, and anterior-posterior axis. Landmarks and reference planes are defined in Table 2 and Fig. 1. The 3D positions of the landmarks and five linear and seven angular variables at $\mathrm{T} 1$ and $\mathrm{T} 2$ stages

Table 1 Demographic data of the patients according to age, sex, genioplasty, time follow-up $C T$ is taken, and mandible setback amount

\begin{tabular}{llllll}
\hline Patient & Age & Sex & Genioplasty $(\mathrm{mm})$ & $\begin{array}{l}\text { Time follow-up } \\
\text { CT is taken }\end{array}$ & $\begin{array}{l}\text { Mandible } \\
\text { setback }(\mathrm{mm})\end{array}$ \\
\hline 1 & 20 & M & Reduction $3 \mathrm{~mm}$ & 1 year & 7 \\
2 & 21 & M & Advance $4 \mathrm{~mm}$ & 2 years & 4 \\
3 & 18 & F & Advance $4 \mathrm{~mm}$ & 1 year & 8 \\
4 & 19 & F & x & 7 months & 6 \\
5 & 18 & F & x & 6 months & 7 \\
6 & 19 & M & Advance $3 \mathrm{~mm}$ & 6 months & 6 \\
7 & 18 & M & x & 10 months & 11 \\
8 & 19 & M & Reduction $3 \mathrm{~mm}$ & 1 year & 7 \\
9 & 19 & F & x & 6 months & 11 \\
10 & 20 & F & Reduction $2 \mathrm{~mm}$ & 6 months & 4 \\
11 & 24 & F & x & 1 year & 7 \\
12 & 29 & M & Advance $3 \mathrm{~mm}$ & 6 months & 10 \\
13 & 23 & F & Advance $3 \mathrm{~mm}$ & 1 year & 7 \\
14 & 18 & M & Advance $5 \mathrm{~mm}$ & 1 year & 3 \\
\hline
\end{tabular}

Table 2 Landmarks and reference planes used in this study Definition

\begin{tabular}{|c|c|}
\hline \multicolumn{2}{|l|}{ Reference landmark } \\
\hline Subnasale (Sn) & $\begin{array}{l}\text { The midpoint of the angle at the columella base } \\
\text { where the lower border of the nasal septum and } \\
\text { the surface of the upper lip meet }\end{array}$ \\
\hline $\begin{array}{l}\text { Labrale superius } \\
(L s)\end{array}$ & The midpoint of the upper vermilion line \\
\hline $\begin{array}{l}\text { Cupid bow point } \\
\text { (CBP) }\end{array}$ & $\begin{array}{l}\text { The most elevated point of the philtrum on the } \\
\text { upper vermilion border line }\end{array}$ \\
\hline $\begin{array}{l}\text { Labrale inferius } \\
\text { (Li) }\end{array}$ & The midpoint of the lower vermilion line \\
\hline $\begin{array}{l}\text { Lower lip bow } \\
\text { point (LLBP) }\end{array}$ & The breakpoint on the lower vermilion border line \\
\hline Stomion (Stm) & $\begin{array}{l}\text { The point at the midline of labial fissure between } \\
\text { gently closed lips }\end{array}$ \\
\hline $\begin{array}{l}\text { Rt. Lt Stomion } \\
(\mathrm{Stm})\end{array}$ & $\begin{array}{l}\text { The breakpoint on the labial fissure line between } \\
\text { gently closed lips }\end{array}$ \\
\hline Cheilion (Ch) & The point located at each labial commissure \\
\hline $\begin{array}{l}\text { Soft tissue B } \\
\text { point (B') }\end{array}$ & $\begin{array}{l}\text { The deepest point on the facial midline, between } \\
\text { the lower lip and chin }\end{array}$ \\
\hline $\begin{array}{l}\text { Lower incisor tip } \\
(\mathrm{L} 1)\end{array}$ & $\begin{array}{l}\text { The midpoint of the incisal edge of the right } \\
\text { mandibular central incisor. }\end{array}$ \\
\hline $\begin{array}{l}\text { Upper lip } \\
\text { prominent (UP) }\end{array}$ & $\begin{array}{l}\text { A line parallel to the passing Ls to Stm touched the } \\
\text { outer most point on upper lip from lateral view }\end{array}$ \\
\hline $\begin{array}{l}\text { Lower lip } \\
\text { prominent (LP) }\end{array}$ & $\begin{array}{l}\text { A line parallel to the passing Li to Stm touched the } \\
\text { outer most point on upper lip from lateral view }\end{array}$ \\
\hline \multicolumn{2}{|l|}{ Reference planes } \\
\hline Horizontal plane & $\begin{array}{l}\text { A plane constructed with the right orbitale, the } \\
\text { right porion, and the left porion (Frankfort } \\
\text { horizontal (FH) plane) }\end{array}$ \\
\hline Coronal plane & $\begin{array}{l}\text { A plane constructed with the right } \\
\text { frontozygomatic suture (FSZ) and left FZS, } \\
\text { perpendicular to the FH plane }\end{array}$ \\
\hline Sagittal plane & $\begin{array}{l}\text { A plane constructed with nasion, perpendicular to } \\
\text { the } \mathrm{FH} \text { and coronal planes }\end{array}$ \\
\hline
\end{tabular}

were measured by a single operator using Ondemand $3 \mathrm{D}^{\mathrm{m}}$ (Table 3 and Figs. 2 and 3). The extent of changes in the landmark and the linear and angular variables between the $\mathrm{T} 1$ and $\mathrm{T} 2$ stages were measured by a single operator using Ondemand program (Tables 3 and 4).

\section{Statistical analyses}

We evaluated the clinical data of retrospective cohort study about 14 patients. The targets were patients who visited the Department of Oral and Maxillofacial Surgery at the Dental Hospital of Wonkwang University during January 2012 October 2015. An independent $t$ test was used to compare the amounts of soft tissue changes with the amounts of hard tissue changes in T1 and T2. The correlations between the soft tissue and hard tissue movements in the horizontal and vertical planes were examined by Pearson 


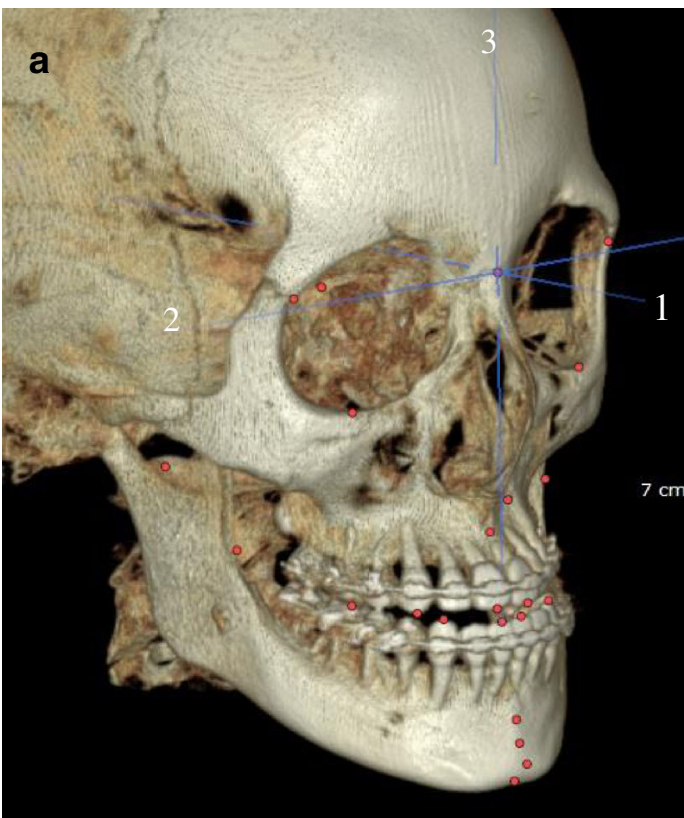

b
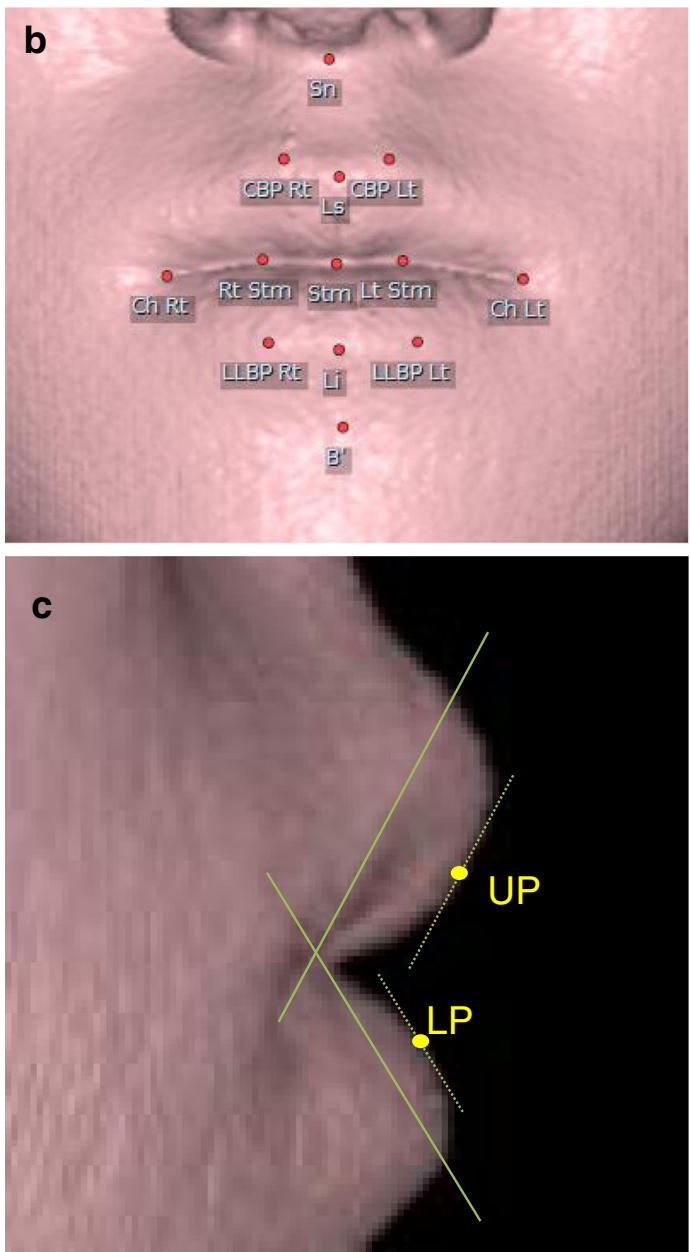

Fig. 1 Landmarks and reference planes. a Reference plane: 1, horizontal plane (Frankfort horizontal plane); 2, coronal plane; 3, sagittal plane. b Soft tissue landmark on frontal view. c Soft tissue landmark on lateral view

correlation analysis. The horizontal ratios of the soft tissue to hard tissue changes in the groups were also compared. We conducted Shapiro-Wilks test to identify this normality test, and all variables had been normally distributed in significant probability over 0.05. A paired $t$ test was performed to analyze the changes of $3 \mathrm{D}$ coordinate values and measurements between before and after the surgery. Statistical analysis was performed using Fisher's exact test and Pearson correlation analysis and with SPSS ver. 12.0.

\section{Results}

The samples consisted of 14 class III patients treated with MSS using bilateral sagittal split ramus osteotomy. The average periods when follow-up cone-beam CT was taken were about 10 months (range $=6$ to 24 months) after operation. Five patients had not undergone genioplasty, three patients had undergone reduction genioplasty, and six patients had undergone advance genioplasty. The mean amount of setback at point B was $5.05 \pm 2.84 \mathrm{~mm}$ (Table 1).

Table 3 Linear and angular variables of the hard and soft tissue

\begin{tabular}{|c|c|}
\hline Reference mark & Definition \\
\hline \multicolumn{2}{|l|}{ Linear variables (mm) } \\
\hline Cheilion width & $\begin{array}{l}\text { Distance between cheilion of the one side } \\
\text { and the other side }\end{array}$ \\
\hline Upper lip height & Distance between Ls and Stm \\
\hline Lower lip height & Distance between Li and Stm \\
\hline $\begin{array}{l}\text { Upper lip vermilion } \\
\text { length }\end{array}$ & $\begin{array}{l}\text { Distance between } C h(R t) \text { and CBP Rt and } L s \\
\text { and CBP Lt and Ch(Lt) }\end{array}$ \\
\hline $\begin{array}{l}\text { Lower lip vermilion } \\
\text { length }\end{array}$ & $\begin{array}{l}\text { Distance between } C h(R t) \text { and LLBP Rt and Li } \\
\text { and LLBP Lt and Ch(Lt) }\end{array}$ \\
\hline \multicolumn{2}{|l|}{ Angular variables $\left({ }^{\circ}\right)$} \\
\hline UL prominence angle & Angle constructed among Ch, Ls, and Ch \\
\hline LL prominence angle & Angle constructed among $\mathrm{Ch}, \mathrm{Li}$, and $\mathrm{Ch}$ \\
\hline $\begin{array}{l}\text { Stomion prominence } \\
\text { angle }\end{array}$ & Angle constructed among Ch, Stm, and Ch \\
\hline $\begin{array}{l}\text { Lateral upper lip } \\
\text { prominent angle } 1\end{array}$ & $\begin{array}{l}\text { Angle constructed among Sn, Ls, and UP in } \\
\text { lateral view }\end{array}$ \\
\hline $\begin{array}{l}\text { Lateral upper lip } \\
\text { prominent angle } 2\end{array}$ & $\begin{array}{l}\text { Angle constructed among } L s, U P \text {, and Stm in } \\
\text { lateral view }\end{array}$ \\
\hline $\begin{array}{l}\text { Lateral lower lip } \\
\text { prominent angle } 1\end{array}$ & $\begin{array}{l}\text { Angle constructed among Stm, } L P \text {, and } L i \text { in } \\
\text { lateral view }\end{array}$ \\
\hline $\begin{array}{l}\text { Lateral lower lip } \\
\text { prominent angle } 2\end{array}$ & $\begin{array}{l}\text { Angle constructed among } L P, L i \text {, and } L n \text { in } \\
\text { lateral view }\end{array}$ \\
\hline
\end{tabular}




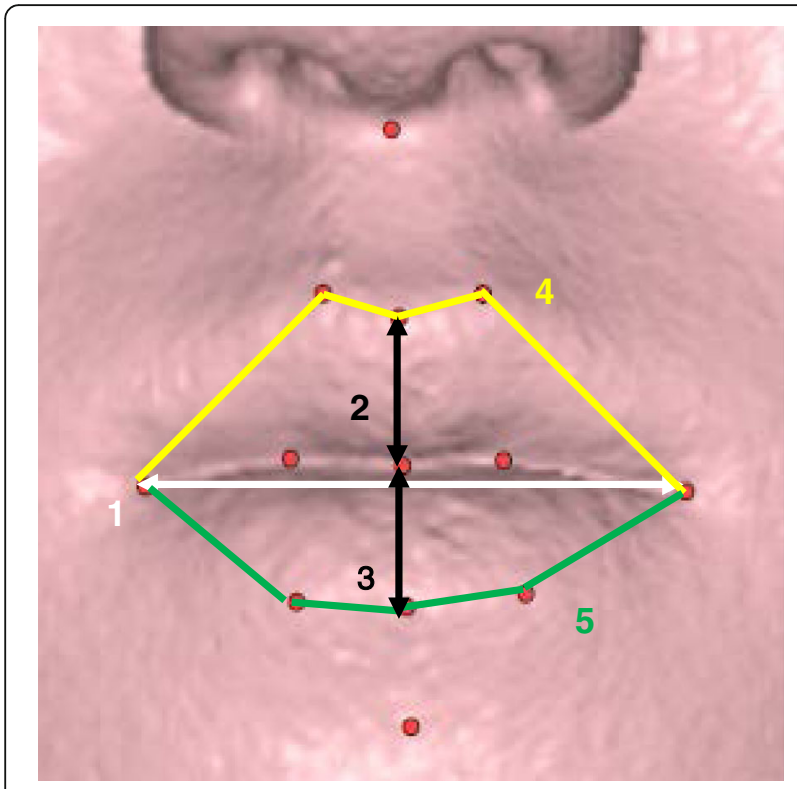

Fig. 2 Linear variables. 1, cheilion width; 2, upper lip height; 3, lower lip height; 4, upper lip vermilion length; and 5, lower lip vermilion length

\section{Change of the hard tissue landmark $(\mathrm{mm})$ between T2 and $\mathrm{T} 1$ stages}

No significant changes in the $3 \mathrm{D}$ position of maxillary hard tissue landmarks were found in either group. Anteroposterior (AP) changes in hard tissue landmarks on $B$ point, pogonion, and L1 were significant in patients. Menton moved superior about $1.2 \mathrm{~mm}$ (Table 4 and Fig. 4).

\section{Change of cheilion, cheilion width, and lip prominence angle}

Landmarks in the cheilion moved backward and downward (respectively 1.8 and $1.2 \mathrm{~mm}, p<.005$ and $p<.01$ ). However, cheilion width was not statistically significantly changed. Landmark in labrale superius (Ls) were not altered significantly. Upper lip prominence angle became acute (ChRt-Ls-ChLt, $5^{\circ}$ decreased, $p<.005$ ). Landmarks in stomion (Stm) and the lower lip (Li) moved backward (Stm, $1.8 \mathrm{~mm}$; Li, $4.3 \mathrm{~mm} ; p<.005, p<.001$, respectively). Lower lip prominence angle became obtuse (ChRt-Li-ChLt, $9^{\circ}, p<.001$ ) (Tables 5 and 6 and Figs. 2 and 3).

\section{Change in lip height, vermilion length, and the lip area}

The height of the upper and lower lips was not altered significantly. The length of the upper lip vermilion was increased $(3.5 \mathrm{~mm}, p<.01)$ and the length of the lower lip vermilion was decreased $(1.9 \mathrm{~mm}, p<.05)$ (Table 7 and Fig. 2). The lip area on frontal view was not statistically significantly changed, but the upper lip area on lateral view was increased and lower lip area decreased (upper lip area $6.3 \mathrm{~cm}^{2}$ increased, lower lip area $15.6 \mathrm{~cm}^{2}$ decreased, $p>.05$ and $p<.005$ ) (Table 9 and Fig. 5).
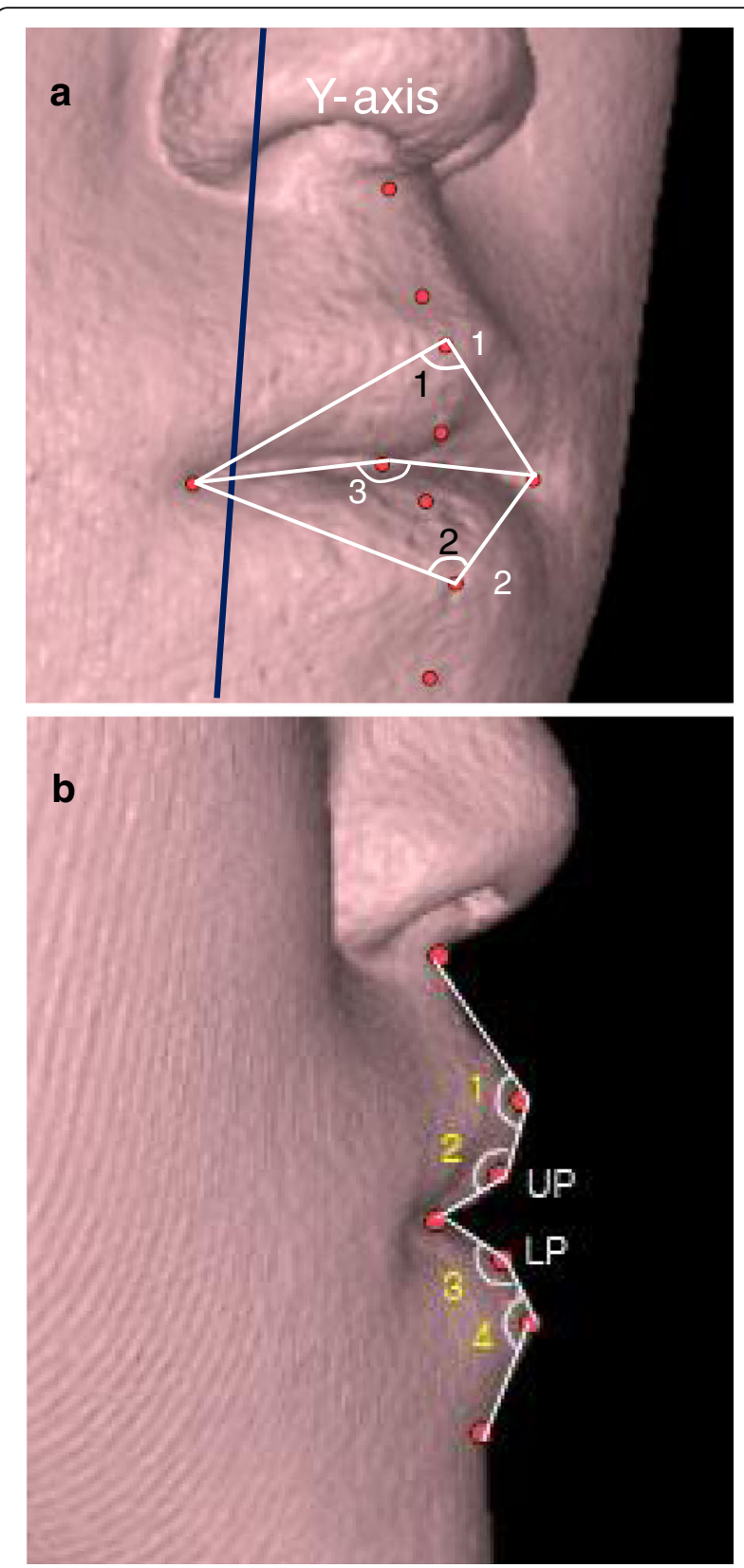

Fig. 3 Angular variables. a 1, UL prominence angle; 2, LL prominence angle; 3, stomion prominence angle. b 1, upper lip prominent angle (1) [Sn-LS-UP ${ }^{\circ}$; 2 , upper lip prominent angle (2) [Ls-UP-Stm ${ }^{\circ}$; 3, lower lip prominent angle (1) [Stm-LP-Li ${ }^{\circ}$; 4, lateral lower lip prominent angle (2) [LP-Li-Ln $\left.{ }^{\circ}\right]$

\section{Change in the 3D linear angles of lip}

On lateral view, upper lip prominent point moved downward (1.24 mm, $p<.05)$ and stomion moved backward and upward (1.79 and $0.63 \mathrm{~mm}, p<.005$ and $p=.103)$ and angle of Ls-UP-Stm $\left(^{\circ}\right)$ was decreased $\left(-9.36^{\circ}, p<.05\right)$. Lower lip prominent point moved backward and downward $(-2.7 \mathrm{~mm}$ and $-2.1 \mathrm{~mm}, p<.05$ and $p<.005)$ and the angle of Stm-LP-Li $\left(^{\circ}\right)$ was increased 
Table 4 Change of the hard tissue landmark $(\mathrm{mm})$ after mandibular setback surgery

\begin{tabular}{llll}
\hline Landmarks & \multicolumn{2}{l}{$\Delta(\mathrm{T} 2-\mathrm{T} 1)(\mathrm{mm})$} & \\
\cline { 2 - 4 } & Mean & $\mathrm{SD}$ & $p$ value \\
\hline$\Delta \mathrm{B}(\mathrm{z})$ & -5.05 & 2.84 & $0.000^{* *}$ \\
$\Delta \mathrm{L} 1(\mathrm{z})$ & -4.63 & 2.34 & $0.000^{* *}$ \\
$\Delta \operatorname{pog}(\mathrm{z})$ & -4.45 & 3.37 & $0.001^{* *}$ \\
$\Delta$ Me(y) & -1.20 & 1.34 & $0.014^{*}$ \\
\hline
\end{tabular}

*Statistically significant difference between the groups $(P<0.05)$

**Statistically significant difference between the groups $(P<0.01)$

$\left(6.43^{\circ}, p=.065\right)$. Li moved only backward $(-4.32, p<.001)$ and not downward. Finally, morphology of the lower lip was protruding (Table 8 and Fig. 6).

\section{Change in the lower incisor tip and stomion}

Landmark in the lower incisor tip (L1) moved backward and upward (-4.63 and $1.33 \mathrm{~mm} ; p<.001$ and $p .084)$, but in stomion, the landmarks moved downward $(0.63 \mathrm{~mm}$; $p=.103)$. Before the surgery, stomion was located higher than L1. After the surgery, L1 was positioned superiorly than stomion $(-1.97 \mathrm{~mm} ; p<.05)$ (Table 10 and Fig. 6).

\section{Correlation between the hard and soft tissue variables}

The following is the result of Pearson coefficient analysis regarding the soft and hard tissue. The most influential landmark is L1, and it was related with cheilion's backward and downward movement $\left(R^{2}=0.67\right.$ and $R^{2}=0.60 ; p<.05$ and $\left.p=.05\right)$ and lower lip prominence angle $\left(\mathrm{Stm}-\mathrm{Y}-\mathrm{Li}^{\circ}\right)(p=.057)$. The upper movement of menton is concerned with increase in stomion prominence angle $\left(\mathrm{ChRt}-\mathrm{Stm}-\mathrm{ChLt}^{\circ}\right)\left(R^{2}=0.59 ; p<.05\right)$ (Table 11).

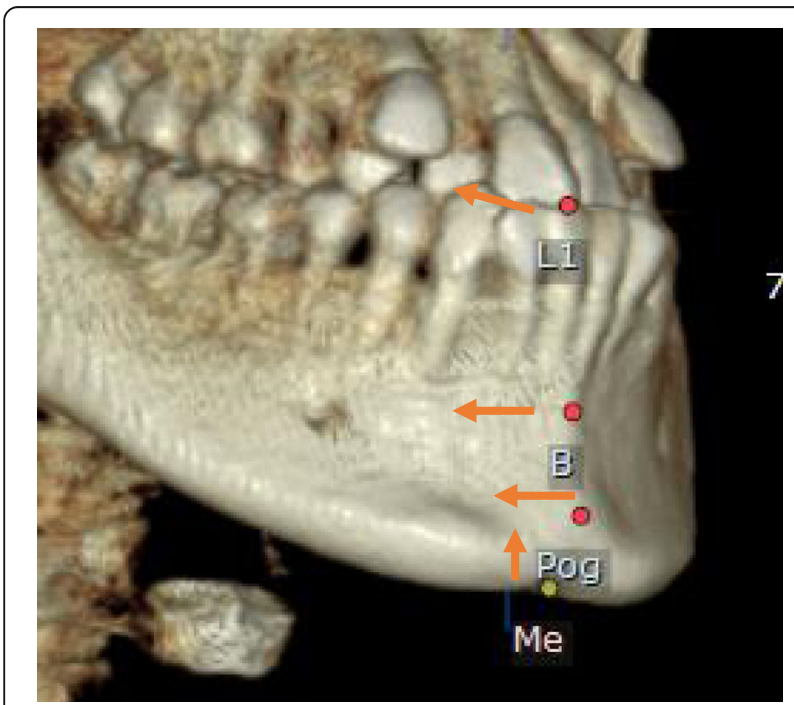

Fig. 4 Change of the hard tissue landmark $(\mathrm{mm})$ between $\mathrm{T} 2$ and T1 stages
Table 5 Change of cheilion position and cheilion width

\begin{tabular}{lcccl}
\hline Variables $(\mathrm{mm})$ & & \multicolumn{4}{c}{$\Delta(\mathrm{T} 2-\mathrm{T} 1)$} \\
\cline { 3 - 5 } & & Mean & $\mathrm{SD}$ & $p$ value \\
\hline Cheilion width & Ch Rt-Ch Lt & 0.97 & 2.62 & 0.245 \\
Cheilion AP position & $\Delta \mathrm{Ch}(\mathrm{z})$ & -1.85 & 1.6 & $0.003^{* *}$ \\
Cheilion vertical position & $\Delta \mathrm{Ch}(\mathrm{y})$ & -1.27 & 1.17 & $0.005^{* *}$ \\
\hline **Statistically significant difference between the groups $(P<0.01)$ &
\end{tabular}

\section{Discussion}

The lip is a structure positioned in the central part of the face, which has important influences on esthetic impression. After orthognathic surgery, the morphological change is inevitable so that accurate understanding about the alteration of soft tissue around lips is required.

Three-dimensional CT may be an effective tool for investigating the $3 \mathrm{D}$ changes in hard and soft tissues simultaneously in terms of direction and amount of movement information that $2 \mathrm{D}$ radiographs and $3 \mathrm{D}$ surface scanning systems cannot provide. If a better algorithm to combine the 3D laser or optical surface scanning and CT without distortional error is developed, it would be a great advance for the clinical research.

In our studies, these showed the same results as the previous studies. There was no change of lip width and decrease in upper prominence angle and lower lip vermilion, but increase of the lower prominence angle and the upper lip vermilion length showed the same results like the previous research [19-21].

Change of cheilion, cheilion width and lip prominence angle There have been controversies over mouth corner (cheilion position) in each study. In our study, landmarks in the mouth corner (cheilion, Ch) moved backward and downward after MSS (respectively 1.8 and $1.2 \mathrm{~mm}, p<.005$ and $p=.005)$. Lim and Baik et al. reported similar results, but Jung et al. reported different results that cheilion moved only backward [19-21]. The result of cheilion moving posteriorly is shown among the three studies. However, regarding the present study and the inferior movement of Lim and Baik's one, the superior movement of Rafiqul after the surgery was the

Table 6 Change of lip prominence angle

\begin{tabular}{lllll}
\hline Lip area & & \multicolumn{4}{l}{$\Delta(\mathrm{T} 2-\mathrm{T} 1)$} \\
\cline { 3 - 5 } & & Mean & $\mathrm{SD}$ & $p$ value \\
\hline Upper lip-related & $\Delta \mathrm{Ls}(\mathrm{z})(\mathrm{mm})$ & -0.18 & 2.00 & 0.765 \\
& $\mathrm{Ch}(\mathrm{Rt})-\mathrm{Ls}-\mathrm{Ch}(\mathrm{Lt})\left(^{\circ}\right)$ & -5.73 & 4.66 & $0.002^{* *}$ \\
\multirow{2}{*}{ Stomion-related } & $\Delta \mathrm{Stm}(\mathrm{z})(\mathrm{mm})$ & -1.79 & 2.48 & $0.003^{* *}$ \\
& $\mathrm{Ch}(\mathrm{Rt})-\mathrm{Stm}-\mathrm{Ch}(\mathrm{Lt})\left(^{\circ}\right)$ & -2.18 & 5.83 & 0.242 \\
Lower lip-related & $\Delta(\mathrm{Li})(\mathrm{z})(\mathrm{mm})$ & -4.32 & 2.49 & $0.000^{* *}$ \\
& $\mathrm{Ch}(\mathrm{Rt})-\mathrm{Li}-\mathrm{Ch}(\mathrm{Lt})\left({ }^{\circ}\right)$ & 8.82 & 4.12 & $0.000^{* *}$ \\
**Statistically significant difference between the groups $(P<0.01)$ &
\end{tabular}


Table 7 Comparison of the change (from T1 to T2) in the upper lip height, lower lip height, upper lip vermilion length, and lower lip vermilion length

\begin{tabular}{llrll}
\hline Variables (mm) & & \multicolumn{4}{c}{$\Delta(\mathrm{T} 2-\mathrm{T} 1)$} \\
\cline { 3 - 5 } & & Mean & $\mathrm{SD}$ & $p$ value \\
\hline Upper lip height & Ls-Stm & 0.76 & 1.42 & 0.105 \\
Lower lip height & Li-Stm & -1.46 & 1.36 & $0.005^{* *}$ \\
$\begin{array}{l}\text { Upper lip vermilion } \\
\text { length }\end{array}$ & Ch(Rt)-CBP Rt-Ls-CBP & 3.54 & 3.59 & $0.008^{* *}$ \\
Lower lip vermilion & Ch(Rt)-LLBP Rt-Li-LLBP & -1.90 & 2.35 & $0.023^{*}$ \\
length & Lt-Ch(Lt) & & & \\
\hline
\end{tabular}

*Statistically significant difference between the groups $(P<0.05)$

**Statistically significant difference between the groups $(P<0.01)$

opposite result [17]. Further study is required for the inferior movement of cheilion.

Cheilion width was not statistically significantly changed. Landmark in labrale superius (Ls) were not altered significantly. It implies that muscle tonicity might not be changed within a short period of time [19]. Also, this means that an increase in the lip length between CBP and Ch was produced by stretching the soft tissues. Posterior and inferior movements of $\mathrm{Ch}$ were also observed in the 3D coordinates.

Upper lip prominence angle became acute (ChRt-LsChLt, $5^{\circ}$ decreased, $p<.005$ ). Landmarks in stomion (Stm) and the lower lip $(\mathrm{Li})$ moved backward $(\mathrm{Stm}, 1.8 \mathrm{~mm}$; Li, $4.3 \mathrm{~mm} ; p<.005, p<.001$, respectively). Lower lip prominence angle became obtuse (ChRt-Li-ChLt, $9^{\circ}, p<.001$ ) (Tables 5 and 6 and Figs. 2 and 3). These results were in accordance with the result of previous studies [19-21].

Before MSS, soft tissue stretching of the chin in the prognathic mandible can pull the upper and lower lips downward. When normal lip posture is achieved after MSS, normal convexity of the upper and lower lips can be restored. 3D soft tissue changes in class III patients after MSS occurred more in the Li than Ls with an increasing gradient. Because there was more backward movement of Li than Ls (4.3 vs. $0.2 \mathrm{~mm}$, Table 6), the positions of the upper and lower lips were affected by the position of lower incisors in class III patients before MSS. However, after MSS, the upper and lower lips were under the influence of the upper incisors. The lower lip tension was reduced after MSS allowing for the formation of a better environment for lip sealing and eventually increase in lower lip prominence angle [20].

\section{Change in lip height, vermilion length and the lip area}

The height of the upper and lower lips was not altered significantly. These results are in accordance with Jung et al. and Baik et al. $[19,21]$. But the height of the lower lip is reported to change statistically significantly. They explain that the position of the lower lip would be influenced by the position of the upper incisors after
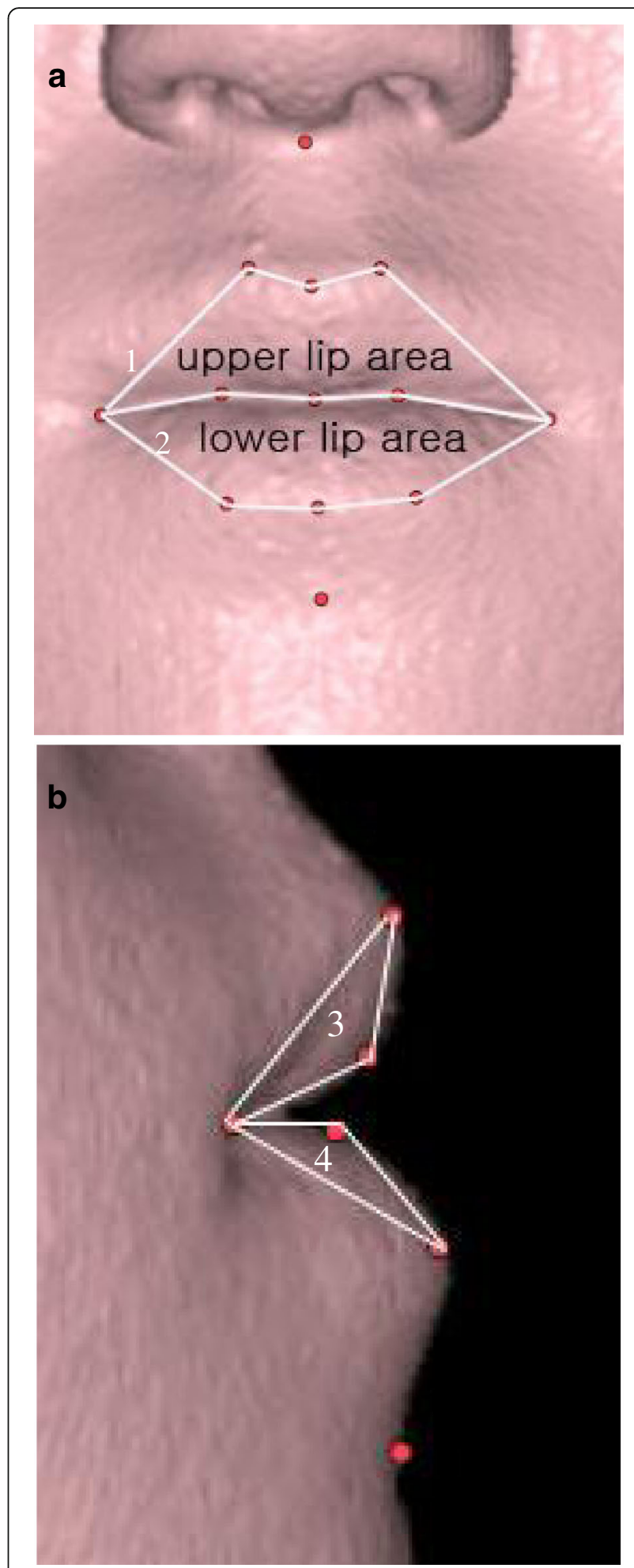

Fig. 5 Lip areas of anterior and side views. a 1 upper lip area of frontal view; 2, lower lip area of frontal view. b 3 upper lip area of lateral view; 4, lower lip area of lateral view 
Table 8 Comparison of the change (from T1 to T2) in lip landmark and linear angles on lateral view

\begin{tabular}{|c|c|c|c|c|}
\hline \multirow{2}{*}{$\begin{array}{l}\text { Variables } \\
(\mathrm{mm})\end{array}$} & & \multicolumn{3}{|c|}{$\underline{\Delta(\mathrm{T} 2-\mathrm{T} 1)}$} \\
\hline & & Mean & SD & $p$ value \\
\hline & UP(y) (mm) & -1.24 & 1.84 & $0.049^{*}$ \\
\hline & Stm(y) (mm) & 0.63 & 1.17 & 0.103 \\
\hline & $\operatorname{Stm}(\mathrm{z})(\mathrm{mm})$ & -1.79 & 2.48 & $0.003^{* *}$ \\
\hline & LP(y (mm)) & -2.1 & 1.54 & $0.001^{* *}$ \\
\hline & $\mathrm{LP}(\mathrm{z})(\mathrm{mm})$ & -2.7 & 3.44 & $0.025^{*}$ \\
\hline & $\mathrm{Li}(\mathrm{z})(\mathrm{mm})$ & -4.32 & 2.49 & $0.000^{* *}$ \\
\hline 1 & Sn-Ls-UP $\left(^{\circ}\right)$ & -3.16 & 11.21 & 0.371 \\
\hline 2 & Ls-UP-Stm $\left(^{\circ}\right)$ & -9.36 & 10.75 & $0.016^{*}$ \\
\hline 3 & Stm-LP-Li $\left(^{\circ}\right)$ & 6.43 & 10.29 & $0.065^{*}$ \\
\hline 4 & LP-Li-Ln $\left(^{\circ}\right)$ & 5.19 & 12.59 & 0.201 \\
\hline
\end{tabular}

* Statistically significant difference between the groups $(P<0.05)$

**Statistically significant difference between the groups $(P<0.01)$

MSS. In addition, lower lip tension could be reduced after MSS and eventually resulted in decrease of the lower lip height and lower vermilion height, which is consistent with Gjørup and Athanasiou [20, 23].

However, the vertical change of the soft tissue after surgery is still difficult to predict. Robinson et al. and Jung et al. reported that changes in the soft tissue did not closely follow those in the hard tissue in the vertical plane compared with the anteroposterior and transverse planes $[19,20,24]$.

The length of the upper lip vermilion was increased ( $3.5 \mathrm{~mm}, p<.01)$ and the length of the lower lip vermilion was decreased $(1.9 \mathrm{~mm}, p<.05)$. After MSS, there is a possibility of decrease in lower lip tension, which would allow for replacement of the upper lip over the lower lip and eventual opposing change in the vermilion border length [20].

On frontal view, the lip area was not statistically significant changed, but the upper lip area on lateral view was increased and the lower lip area decreased after MSS $\left(6.3 \mathrm{~cm}^{2}, p=.078,-15.6 \mathrm{~cm}^{2}, p<.005\right)$. This is due to the cheilion which moved backward and downward and labrale inferius which moved backward. These changes make the facial profile more esthetic in class III patients (Table 5, 9 and Fig. 5).

\section{Change in the 3D linear angles of lip}

On lateral view, the upper lip prominent point moved downward $(1.24 \mathrm{~mm}, p<.05)$ and stomion moved backward and upward (1.79 and $0.63 \mathrm{~mm}, p<.005$ and $p=.103)$ and the angle of Ls-UP-Stm $\left({ }^{\circ}\right)$ was decreased $\left(-9.36^{\circ}, p<.05\right)$ (Table 8). The lower lip prominent point moved backward and downward $(-2.7$ and $-2.1 \mathrm{~mm}$, $p<.05$ and $p<.005)$ and the angle of Stm-LP-Li $\left({ }^{\circ}\right)$ was increased $\left(6.43^{\circ}, p .065\right)$ (Table 8 ). Li moved only
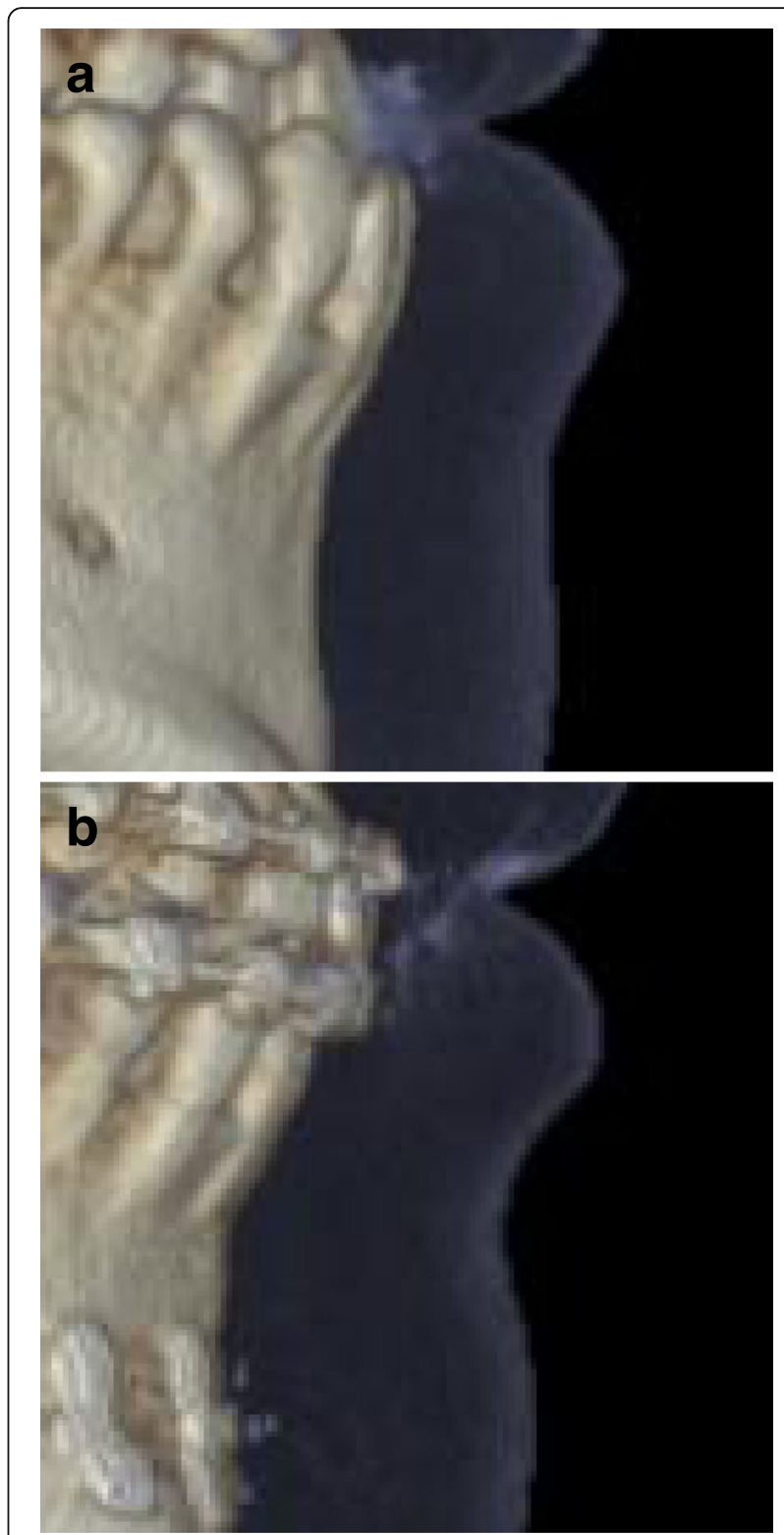

Fig. 6 Change in the lower incisor tip and stomion. a Morphology in the lower incisor tip and stomion before MSS. b Morphology in the lower incisor tip and stomion after MSS

Table 9 Comparison of the change (from T1 to T2) in the lip area

\begin{tabular}{llcll}
\hline Lip area $\left(\mathrm{cm}^{2}\right)$ & & \multicolumn{2}{c}{$\Delta(\mathrm{T} 2-\mathrm{T} 1)$} & \\
\cline { 3 - 5 } & & Mean & SD & p value \\
\hline Upper lip & Lateral view & 6.28 & 10.59 & $0.078^{*}$ \\
& Frontal view & 8.21 & 45.18 & 0.560 \\
\multirow{2}{*}{ Lower lip } & Lateral view & -15.57 & 10.33 & $0.001^{* *}$ \\
& Frontal view & -12.69 & 41.46 & 0.334 \\
\hline
\end{tabular}

*Statistically significant difference between the groups $(P<0.05)$

**Statistically significant difference between the groups $(P<0.01)$ 
Table 10 Comparison of the change (from T1 to T2) in lower incisor lip and stomion

\begin{tabular}{|c|c|c|c|c|c|c|c|c|c|}
\hline & $\Delta \mathrm{T} 1$ & & & $\Delta \mathrm{T} 2$ & & & $\Delta(\mathrm{T} 2-$ & & \\
\hline & Mean & SD & & Mean & SD & & Mean & SD & $p$ value \\
\hline$\Delta \mathrm{L} 1(\mathrm{y})(\mathrm{mm})$ & 82.35 & 6.48 & 0.000 & 82.84 & 5.62 & 0.000 & -1.33 & 2.30 & 0.084 \\
\hline$\Delta \operatorname{Stm}(\mathrm{z})(\mathrm{mm})$ & & & & & & & -1.79 & 2.48 & $0.003^{* *}$ \\
\hline$\Delta \mathrm{Stm}(\mathrm{y})(\mathrm{mm})$ & 84.17 & 7.40 & 0.000 & 82.99 & 6.24 & 0.000 & 0.63 & 1.17 & 0.103 \\
\hline$\Delta \operatorname{Stm}(\mathrm{y})-\Delta \mathrm{L} 1(\mathrm{y})(\mathrm{mm})$ & 1.81 & 2.84 & 0.060 & -0.15 & 2.4 & 0.834 & -1.97 & 2.17 & $0.013^{*}$ \\
\hline
\end{tabular}

*Statistically significant difference between the groups $(P<0.05)$

**Statistically significant difference between the groups $(P<0.01)$

backward $(-4.32, p<.001)$ and not downward. Finally, morphology of the lower lip was protruding (Table 8 and Fig. 6).

The eversion of the lower lip became distinct, and a more natural lip line was formed. After the surgery, the outcome of the lower lip eversion is shown in other studies as well [17, 19-21]. Three-dimensional optical surface scans could measure the magnitude of change and show a significant eversion of the lower lip, which was reported by Hershey and Smith [23].

In that study, using the thin-plate spline analysis, the forward movement of stomion inferius was shown, while labrale inferius was moving backward, displaying the eversion of the lower lip and increasing the lower vermilion border in most class III cases. This was because the relaxation of the lower lip after the tension caused by the lower teeth and the alveolar bone was eliminated with a mandibular setback, eventually eliminating lip incompetence and forming a better lip seal.

\section{Change in the lower incision tip and stomion}

Landmarks in the lower incisor tip (L1) moved backward and upward but, in stomion moved downward. After surgery, L1 was positioned superiorly than stomion $(-1.97 \mathrm{~mm}, p<.05)$ (Table 10 and Fig. 6). According to Robinson, Ls and Li moved inferiorly, even though almost all hard tissue landmarks had moved superiorly. This was because the free ends of the upper and lower lips interfered with the contacting incisor surface and the opposite lips recovered by moving downward [24].

\section{Correlation between the hard and soft tissue variables}

The following is the result of Pearson coefficient analysis regarding the soft and hard tissue. The most influential landmark is L1, and it was related with cheilion posterior movement $(p<.05$ and $p=.05)$ and lower lip prominence angle $\left(\mathrm{Stm}-\mathrm{Y}-\mathrm{Li}^{\circ}\right)(p=0.057)$. The upper movement of menton is concerned with increase in stomion prominence angle (ChRt-Stm-ChLt $\left.{ }^{\circ}\right)(p<.05)$ (Table 11). These changes may be a contributing factor that the lower lip makes eversion and is more esthetic. Perhaps, decrease of muscle tension might change the prominent angle of the upper lip and lower lip at lateral view. It might make the form of the lip esthetically and eversion.

Lip commissure was seemed to be positioned higher in postoperative phase than in preoperative phase. It may be due to increase of lip thickness. Finally, lip morphology seems to be improved in the view of esthetics after orthognathic surgery (one jaw) for mandibular prognathism.

After mandibular setback, the position of the lip commissure tended to be higher, and the amount of $1.27 \mathrm{~mm}$ was not a few changes. This amount of changes was statistically significant.

Because of the limited number of the included patients in this study, authors could not analyze how much genioplasty affects the changes of lip morphology. Afterwards, there would be a research more focus on the change in lip morphology according to genioplasty or non-genioplasty group based on significant number of patients. Two-jaw surgery is more influencing on the muscle and soft tissue than one-jaw surgery, and further research on the lip change is needed. Further researches are needed to be followed on this topic, and it would help us to predict the changes of lip morphology according to the orthognathic surgery.

Table 11 Correlation between the anteroposterior (AP) and vertical $(V)$ changes in the hard and soft tissue variables

\begin{tabular}{|c|c|c|c|}
\hline \multicolumn{2}{|c|}{ Correlation variables } & \multirow{2}{*}{$\begin{array}{l}R^{2} \\
0.737\end{array}$} & \multirow{2}{*}{$\frac{p \text { value }}{0.010^{* *}}$} \\
\hline$\Delta \mathrm{B}(\mathrm{z}) \mathrm{vs}$ & $\Delta \mathrm{Li}(\mathrm{z})(\mathrm{mm})$ & & \\
\hline \multirow[t]{5}{*}{$\Delta \mathrm{L} 1(\mathrm{z}) \mathrm{vs}$} & $\Delta \mathrm{Ch}(\mathrm{y})(\mathrm{mm})$ & 0.602 & $0.050^{*}$ \\
\hline & $\Delta \mathrm{Ch}(\mathrm{z})(\mathrm{mm})$ & 0.671 & $0.024^{*}$ \\
\hline & $\Delta \mathrm{Li}(\mathrm{z})(\mathrm{mm})$ & 0.848 & $0.001^{* *}$ \\
\hline & $\Delta \operatorname{Stm}(\mathrm{z})(\mathrm{mm})$ & 0.745 & $0.008^{* *}$ \\
\hline & $\Delta$ Stm-Y-Li $\left({ }^{\circ}\right)$ & 0.588 & $0.057^{*}$ \\
\hline$\Delta \operatorname{Pog}(\mathrm{z}) \mathrm{vs}$ & $\Delta \mathrm{Li}(\mathrm{z})(\mathrm{mm})$ & 0.629 & $0.038^{*}$ \\
\hline$\Delta \mathrm{Me}(\mathrm{y}) \mathrm{vs}$ & $\Delta$ Ch Rt-Stm-Ch Lt $\left(^{\circ}\right)$ & 0.646 & $0.032^{*}$ \\
\hline
\end{tabular}

*Statistically significant difference between the groups $(P<0.05)$

**Statistically significant difference between the groups $(P<0.01)$

Correlations and ratios of the anteroposterior and vertical changes between the hard and soft were examined. Pearson correlation analysis was done. Ratio $\left(R^{2}\right)$ means amount of change in the soft tissue/amount of change in the hard tissue. Positive (+) value, the change with the same direction; negative $(-)$ value, the opposite direction 


\section{Conclusions}

Three-dimensional evaluation using $3 \mathrm{D}$ cone-beam CT is a valuable tool for assessing the postsurgical changes in movements and allows assessment of changes that 2D imaging modalities do not. The 3D soft tissue changes in class III patients after MSS did exhibit increased gradients from the upper lip and the lower lip to the chin and from the midline (Stm) to the lateral area (Ch).

\section{Funding}

This paper was supported by Wonkwang University in 2015.

\section{Authors' contributions}

WJP helped to draft the manuscript. JYY and JWL performed the statistical analysis. MGC and YDC had been involved in drafting the manuscript or revising it critically for important intellectual content. EJC participated in the sequence alignment. SJP and KHK had made substantial contributions to the conception and the design and interpretation of data. All authors read and approved the final manuscript.

\section{Competing interests}

The authors declare that they have no competing interest.

\section{Consent for publication}

Written informed consent was obtained from the patient for publication of this case report and any accompanying images. A copy of the written consent is available for review by the Editor-in-Chief of this journal.

\section{Ethics approval and consent to participate}

All procedures performed in studies involving human participants were in accordance with the ethical standards of the institutional and/or national research committee and with the 1964 Helsinki declaration and its later amendments or comparable ethical standards. This paper was approved by Institutional Review Board of Wonkwang Dental Research Institute. The number of Institutional Review Board is WKDIRB201510-02.

\section{Author details}

${ }^{1}$ Department of Oral and Maxillofacial Surgery, College of Dentistry and Dental Hospital, Wonkwang University, Iksan, South Korea. ${ }^{2}$ Department of Oral and Maxillofacial Surgery, Wonkwang Dental Research Institute, College of Dentistry, Wonkwang University, 460, Iksan-daero, Iksan, Jeollabuk-do 570-749, South Korea.

Received: 10 June 2016 Accepted: 6 September 2016 Published online: 05 October 2016

\section{References}

1. Jokic D, Jokic D, Uglesic V, Macan D, Knezevic P (2013) Soft tissue changes after mandibular setback and bimaxillary surgery in class III patients. Angle Orthod 83:817-23

2. Arnett GW, Jelic JS, Kim J, Cummings DR, Beress A, Worley CM Jr et al (1999) Soft tissue cephalometric analysis: diagnosis and treatment planning of dentofacial deformity. Am J Orthod Dentofacial Orthop 116:239-53

3. Hoffmann J, Westendorff C, Leitner C, Bartz D, Reinert S (2005) Validation of 3D-laser surface registration for image-guided cranio-maxillofacial surgery. J Craniomaxillofac Surg 33:13-8

4. Katsumata A, Fujishita M, Maeda M, Ariji Y, Ariji E, Langlais RP (2005) 3D-CT evaluation of facial asymmetry. Oral Surg Oral Med Oral Pathol Oral Radiol Endod 99:212-20

5. Bjork N, Eliasson S, Wictorin L (1971) Changes of facial profile after surgical treatment of mandibular protrusion. A cephalometric study, 1 and 11 years after treatment. Scand J Plast Reconstr Surg 5:41-6

6. Fromm B, Lundberg M (1970) The soft-tissue facial profile before and after surgical correction of mandibular protrusion. Acta Odontol Scand 28:157-77

7. Arnett GW, Bergman RT (1993) Facial keys to orthodontic diagnosis and treatment planning. Part I. Am J Orthod Dentofacial Orthop 103:299-312

8. Proffit WR (2000) The soft tissue paradigm in orthodontic diagnosis and treatment planning: a new view for a new century. J Esthet Dent 12:46-9
9. Kerns LL, Silveira AM, Kerns DG, Regennitter FJ (1997) Esthetic preference of the frontal and profile views of the same smile. J Esthet Dent 9:76-85

10. Baik HS, Lee HJ, Lee KJ (2006) A proposal for soft tissue landmarks for craniofacial analysis using 3-dimensional laser scan imaging. World J Orthod 7:7-14

11. Grayson B, Cutting C, Bookstein FL, Kim H, McCarthy JG (1988) The threedimensional cephalogram: theory, technique, and clinical application. Am J Orthod Dentofacial Orthop 94:327-37

12. Bergersen EO (1980) Enlargement and distortion in cephalometric radiography: compensation tables for linear measurements. Angle Orthod 50:230-44

13. Terajima M, Nakasima A, Aoki Y, Goto TK, Tokumori K, Mori N et al (2009) A 3-dimensional method for analyzing the morphology of patients with maxillofacial deformities. Am J Orthod Dentofacial Orthop 136:857-67

14. Kim KD, Ruprecht A, Wang G, Lee JB, Dawson DV, Vannier MW (2005) Accuracy of facial soft tissue thickness measurements in personal computerbased multiplanar reconstructed computed tomographic images. Forensic Sci Int 155:28-34

15. Vannier MW, Marsh JL, Warren JO (1984) Three dimensional CT reconstruction images for craniofacial surgical planning and evaluation. Radiology 150:179-84

16. Fuhrmann RA, Schnappauf A, Diedrich PR (1995) Three-dimensional imaging of craniomaxillofacial structures with a standard personal computer. Dentomaxillofac Radiol 24:260-3

17. Islam R, Kitahara T, Naher L, Hara A, Nakata S (2010) Lip morphology changes following orthognathic surgery for class III malocclusion. Angle Orthod 80:344-53

18. Yuan L, Shen G, Wu Y, Jiang L, Yang Z, Liu J et al (2013) Three-dimensional analysis of soft tissue changes in full-face view after surgical correction of skeletal class III malocclusion. J Craniofac Surg 24:725-30

19. Jung YJ, Kim MJ, Baek SH (2009) Hard and soft tissue changes after correction of mandibular prognathism and facial asymmetry by mandibular setback surgery: three-dimensional analysis using computerized tomography. Oral Surg Oral Med Oral Pathol Oral Radiol Endod 107(763-71), e8

20. Lim YK, Chu EH, Lee DY, Yang IH, Baek SH (2010) Three-dimensional evaluation of soft tissue change gradients after mandibular setback surgery in skeletal class III malocclusion. Angle Orthod 80:896-903

21. Baik HS, Kim SY (2010) Facial soft-tissue changes in skeletal Class III orthognathic surgery patients analyzed with 3-dimensional laser scanning. Am J Orthod Dentofacial Orthop 138:167-78

22. Kau CH, Cronin AJ, Richmond S (2007) A three-dimensional evaluation of postoperative swelling following orthognathic surgery at 6 months. Plast Reconstr Surg 119:2192-9

23. Hershey HG, Smith LH (1974) Soft-tissue profile change associated with surgical correction of the prognathic mandible. Am J Orthod 65:483

24. Robinson SW, Speidel TM, Isaacson RJ, Worms FW (1972) Soft tissue profile change produced by reduction of mandibular prognathism. Angle Orthod 42:227-235

\section{Submit your manuscript to a SpringerOpen ${ }^{\circ}$ journal and benefit from:}

- Convenient online submission

- Rigorous peer review

- Immediate publication on acceptance

- Open access: articles freely available online

- High visibility within the field

- Retaining the copyright to your article

Submit your next manuscript at $>$ springeropen.com 